\title{
Revitalising and preserving endangered indigenous languages in South Africa through writing and publishing ${ }^{\prime}$
}

\author{
Patrick Ngulube ${ }^{2}$ \\ Department of Interdisciplinary Research of the College of Graduate Studies, University of South Africa
}

"The limits of my language mean the limits of my world" (Ludwig Wittgenstein, Austrian-British philosopher, 1889-195I).

Received 10 March 2012

Accepted 10 June 2012

\begin{abstract}
Libraries and librarians play a central role in organising and communicating knowledge. They are an important part of the knowledge production and use chain. The development and sustenance of a knowledge-based economy hinges on their ability to facilitate the accessibility, retrievability and usability of the knowledge and information that permeates the information society. Writers and publishers as part and parcel of the knowledge chain are central to the production and distribution of ideas. Language is fundamental to their ability to communicate and get their literal messages, expressions and ideas through. Their preferred language of writing and publishing may mean a difference between the growth and demise of a language of a society and its culture and civilisation. Many indigenous languages around the globe are struggling to survive because of various reasons including neglect by writers and publishers. Publishers and writers as major role players in the knowledge production and reproduction chain may assist in promoting and preserving indigenous languages in general and in South Africa in particular. This may ensure that South Africa's knowledge economy develops without sidelining or discriminating against any culture or language. There are challenges and opportunities that writers and publishers are likely to face in attempting to revitalise and empower indigenous languages in South Africa, but they are not insurmountable. Using a theoretical approach, the purpose of this article is to highlight the role that writers and publishers may play in revitalising and preserving endangered indigenous languages in South Africa. Recommendations are made on how the role players may deal with the challenges that have culminated in the neglect of the endangered indigenous languages.
\end{abstract}

Keywords: Culture; indigenous languages; Khoe-san languages; publishing; South Africa

\section{Introduction and background}

Libraries and librarians play a pivotal role in organising and communicating knowledge. With writers and publishers, they are part and parcel of the knowledge production and use continuum. The development and sustenance of a knowledgebased economy hinges on the ability of librarians and libraries to facilitate the accessibility, retrievability and usability of the knowledge and information that typifies the information society on the one hand, and the publication of literary works by authors and publishers on the other. Knowledge becomes explicit through language. The majority of reading materials in South Africa are published predominantly in English and Afrikaans at the expense of indigenous languages (Fredericks \& Mvunelo 2003). Publishing and writing in indigenous languages in South Africa has been neglected (Motsaathebe 20I I). Writing about the situation in Namibia, Reiner (2011:319) concluded that: "Unfortunately, many countries on the continent have neglected the most important tools in the trade of African language publishing - African languages - in favour of official languages..."

There is significant reluctance on the part of both the authors and publishers to produce indigenous titles because some languages are perceived to have a small market, and many rural people are thought to have limited disposable income. Publishing is a business concern and publishers must remain viable, but it is our argument that first and foremost publishing should serve a cultural, intellectual and social purpose rather than a commercial purpose per se. Publishers in South Africa should publish works in minority indigenous languages in order to end the siege of the II official languages on the minority indigenous languages that are tottering on the brink of extinction.

Without publishers authors write in vain because publishers stand at the centre of the process of empowering authors and indeed the society. In other words, without a publisher there is no book. There is a communication and production chain at play starting with a mainly oral society "writing" its own primarily transient "biography" and history, or what Mutloatse (1992:2II) terms "volumes of unwritten indigenous prose", followed by the authors extracting various aspects of interest from the "biography" and repackaging them and giving them form and structure and then passing them on to publishers who configure and brand them for consumption by the readers in society.

I. This a reworked version of a paper presented at the Centre of the Book the Second Writers' Symposium held on 8-10 March 20I2, Cape Town, South Africa.

2. Patrick Ngulube (PhD) is Professor in the Department of Interdisciplinary Research in the College of Graduate Studies, University of South Africa. 
Drawing upon the simplified form of the classical communication model of Shannon and Weaver (1949), the publishing process may be further conceptualised starting with the author as the "source" of the material to be published: the publisher as the "transmitter" and the reader as the "recipient". Although Shannon and Weaver (1949) envisaged a telephone network as linking the source and the recipient, it can also be conveniently applied to the role of language in the chain of communication in the context of publishing. Language is central to the ability of the writers to communicate and transmit their literary messages, expressions, philosophies and ideas for present and future use. Verbal and sign languages are the primary means of communication among people and that is what mainly distinguishes them from animals. Interactions and social relationships depend on language. In this regard, language defines humanity.

If language enables human beings to act together, organise themselves into social groups and units and put into effect group decisions, then its demise signals danger for the society in question: in other words, the demise of a language means the end of a culture. Writing and publishing in a language is one of the ways of preserving it for the present and future and ensuring that it is not neglected. Indeed, "written literature and orature are the main means by which a particular language transmits the images of the world contained in the culture it carries" (Ngugi 1986:15).

Many writers and publishers in the world and indeed in South Africa use the language of power to communicate their literary messages. This means that those languages that are at the periphery and are not recognised as official are marginalised and faced with certain extinction. In fact, many indigenous languages around the globe are struggling to survive due to a lack of systemic support. There is a proposition that of an estimated 6,000 languages spoken worldwide, by $2050,80 \%$ of this diversity could be lost (Kraus 1992). Moseley (2010) and Sithole (200I) remind us that a number of indigenous languages are in peril and face extinction if urgent and serious measures are not taken to develop them and elevate their status. These languages need urgent renewal, revitalisation and empowerment to survive. Indigenous people should be empowered through the revitalisation of their languages so that they can play a part in economic development and social upliftment, and mutual enrichment.

For the purpose of this article, indigenous people are regarded as the traditional inhabitants of their lands prior to colonisation by foreigners (Burger 1990). The criteria for the identification of indigenous people vary from country to country, but this a debate that goes beyond the scope of this article. Even if many indigenous languages in South Africa are threatened with extinction we will focus on the Khoe and San languages. The lessons drawn from the revitalisation and empowerment of these languages may be applied to the other indigenous languages of South Africa with certain modifications. These communities were chosen because they have been socially marginalised and very often victimised by the people that they came into contact with over the years in their historical evolution. According to Prah (2003:3), "The most significant victimisation that is going on in the present age is the neglect of their languages and a concerted effort to assimilate them into so-called modernity". In fact, "[w]ithout doubt, the most threatened linguistic communities in South Africa are the Khoe Khoe and San languages groups" (Prah 2006:27). Fredericks and Mvunelo (2003) excluded these languages groups in their study for practical reasons. Our argument is that by focusing on these languages, though no empirical evidence was collected to determine the publishing patterns in these language groups, we are likely to keep the debate going on the preservation of these languages.

The United Nations Educational, Scientific, and Cultural Organization (UNESCO) classified the Khoe Khoe and San languages such as !Gan!ne, Cape Khoekhoe, Korana, N/uu, Xiri, /'Auni, /Xam, //Ku//'e, //Kx'au and //Xegwi as being in danger of disappearing forever (Moseley 2010). According to the UNESCO's Language Vitality and Endangerment Framework there are no speakers left in South Africa for seven of these languages (Moseley 2010). The seven languages include Korana, Nghuki, Seroa, /Xam, //Xegwi, and Xiri (Department of Arts, Culture, Science and Technology 1996: I 72; Prah 2006:27; Sommer 1992:303). These languages are endangered partly due to globalisation and the Afrikanerisation of these communities over the decades. While many governments in the world recognise cultural diversity in line with the UNESCO Universal Declaration on Cultural Diversity, the recognition of only II languages in South Africa as official is an indictment of these languages.

Publishers and writers have not helped the situation. For instance, publishers tend to prioritise the marketing dynamics at the expense of minority languages. On the other hand, indigenous authors write in English or in indigenous languages recognised by the government because they believe that the marketability of their product depends on writing in those official languages. For example, in Zimbabwe priority is given to writing and publishing in Shona and isiNdebele and in South Africa the emphasis seems to be on isiXhosa, isiZulu, isiNdebele, Sepedi, Sesotho, Setswana, Siswati, Tshivenda and Xitshonga at the expense of other indigenous languages. The question is: what is to be done if these languages are not to disappear? Everybody has a role to play, and writers and publishers have a particularly important role that they can play.

The knowledge economy in South Africa may develop in a holistic manner without sidelining or discriminating against any culture or language if writers and publishers play their part. This would also be in line with the provisions of Section 
3I of the South African Constitution which underscores that: "persons belonging to a cultural, religious or linguistic community may not be denied the right, with other members of that community, to enjoy the culture, practise their religion and use their language and to form, join and maintain cultural, religious and linguistic associations and other organs of civil society." Despite this constitutional provision, publishing in indigenous languages remains largely underdeveloped (Book Development Council of South Africa 1997). In fact, it has been often ignored by policy makers as they are mainly concerned with problems related to health, housing and other social and economic amenities.

\section{Endangered indigenous languages should be preserved}

There are a variety of reasons why endangered indigenous languages should be promoted and revitalised (Moseley 20 I0; Prah 2006; Reyhner 1999; Sithole 200I; Sommer 1992; Sure 2006). The preservation and revival of endangered indigenous languages of societies in South Africa is vital because it opens a number of possibilities and opportunities for indigenous people which would:

- assist in refiguring structural and cultural inequalities;

- facilitate the preservation of their tangible and intangible value systems;

- preserve the cultural identity of the indigenous people and avoid the cultural difficulties associated with using other people's languages;

- foster diversity in society and the need to be tolerant;

- enable the acquisition of all varieties of information;

- develop high levels of literacy;

- facilitate full participation in all sectors of the economy;

- reduce the inequalities associated with the privileged status of the II official languages;

- permit people to communicate their expectations to the government without difficulties associated with understanding the languages of power; and make it possible to protect the linguistic rights enshrined in the constitution.

In a nutshell, the preservation and promotion of the languages of indigenous people may ensure their inclusion in the process of "higher level communication for professional, economic, educational and cultural purposes" (Feather 2003:19). People expressing themselves in their indigenous languages will be able to actively participate in civil society. The flow of information between government structures and the indigenous people will improve if indigenous languages are employed and it would be simpler to hold the government accountable. This would help indigenous people to have a meaningful communicative relationship with those who govern them (McLaughlin 2008:12I). Development cannot be attained in a situation where the national communication network is "based exclusively on non-indigenous languages" (Chakava 1996: 26). Put differently:

A people that loses its language or languages is a people that loses its words, and when a people loses its words, it loses its soul and vision of the world. When this happens the community in question becomes lodged in dependence that lasts until it recovers its words and begins to articulate its past, present and future, nationally and internationally (Kum'a Ndumbe III 2007:39).

\section{Linguistic rights as human rights}

Many writers including the Department of Arts, Culture, Science and Technology (1996), Prah (2006) and Thondhlana (2002) have emphasised that linguistic entitlements are a human right. The Harare Declaration of 1997 which emanated from the UNESCO inter-governmental conference on language policies in Africa underscored the need for respect of "linguistic rights as human rights" (Thondhlana 2002:3I). However, many people are not aware of their language rights nor the appropriate channels of complaint and redress. In South Africa, the Pan South African Language Board (PanSALB) was established to promote multilingualism partly through investigating complaints about language violations from an individual, organisation or institution as envisaged in the 1994 Bill of Rights (Pan South African Language Board, n.d). However, the challenge is that many citizens are not aware of the role of this monitoring body. Perhaps more advocacy work is needed to make citizens aware of their linguistic rights.

The 1994 Bill of Rights stated that, "Everyone has the right to use the language and to participate in the cultural life of their choice, but no one exercising these rights may do so in a manner inconsistent with any provision of the Bill of Rights." In addition, the point is made that:

Persons belonging to a cultural, religious or linguistic community may not be denied the right, with other members of that community (a) to enjoy their culture, practise their religion and use their language; and (b) to form, join and maintain cultural, religious and linguistic associations and other organs of civil society (South Africa 1996). 
It is further stated that these rights "may not be exercised in a manner inconsistent with any provision of the Bill of Rights" (South Africa 1996 section 30). By this statement the government committed itself to promoting linguistic and cultural diversity and multilingualism.

The progressive commitment made on paper was going to be partly implemented by the Commission for Promotion and Protection of the Rights of Cultural, Religious and Linguistic Communities whose primary objective is:

to promote respect for the rights of cultural, religious and linguistic communities; to promote and develop peace, friendship, humanity, tolerance and national unity among cultural, religious and linguistic communities, on the basis of equality, non-discrimination and free association; and to recommend the establishment or recognition, in accordance with national legislation, of a cultural or other council or councils for a community or communities in South Africa (South Africa 1996).

Many are disappointed and frustrated by the fact that the linguistic right has remained a paper tiger. The commitment that was made on paper has not been translated into reality. Little progress has been made in developing indigenous languages in general and the endangered ones in particular. Partial "practical and positive measures to elevate the status and advance the use" of indigenous languages as envisaged in the South African Constitution (Act 108 of 1996) have been undertaken. In fact, "functional multilingualism" has remained an elusive dream. The problem seems to partly stem from a lack of political will (Webb 2002). While public/private partnership may represent the best opportunity for preserving indigenous languages, government has a major role to play in uplifting the status of endangered indigenous languages and promoting publishing and writing in those languages. For instance, Afrikaans rose to become a language of power due to the support it enjoyed from the Afrikaner government. Practical steps were taken to promote it.

The major question then that one may ask is: Why is there is little "will" among the political principals? Generalised arguments have been offered without the backing of empirical evidence. Research needs to be conducted in order to establish the reasons behind the government's ineptitude in handling the language question in South Africa. McLaughlin (2008: I 2 I) laments the lack of empirical research to determine the perceived lack of will in implementing progressive language policies in South Africa.

\section{Government policies and the development of indigenous languages}

Government language policy is fundamental to safeguarding endangered indigenous languages and influencing patterns of writing and publishing. According to Dirar (2000:7I), "[a] national language policy enables decision makers to make choices about language issues in a rational comprehensive and balanced way". However, many countries in Africa do not have well articulated policies (Spio-Garbrar 2000:II). Fortunately, in South Africa, the constitutional provisions on the protection and promotion of the major indigenous languages and the minority ones are very clear. The South African Constitution recognises nine of the indigenous languages as official languages. They include SePedi, SeSotho, SeTswana, siSwati, TshiVenda, XiTsonga, isiNdebele, isiXhosa and isiZulu. A country's language policy may have a significant impact on the development and continued existence of a local publishing industry (Reiner 201 I:319).

The South African Constitution embraces multiculturalism. To put the provision of the Constitution into effect, the Pan South African Language Board (PANSALB) was established in terms of Act 59 of 1995 (amended by Act 10 of 1999) to "promote, and create conditions for, the development and use of, all official languages; the Khoe Khoe and San languages; and South African Sign language; and promote and ensure respect for all languages commonly used by communities in South Africa..." (South Africa 1996). Although such progressive policies exist on paper, their implementation has in many respects fallen far short of expectations (Prah 2006). The fact that a Languages Bill is before the parliament of South Africa (Mdletshe 2012) illustrates the fact that the policy of establishing a multilingual society in South Africa is yet to work.

An attempt to assert the usage of other indigenous language in the face of the hegemony of the II official languages is hindered by the existence of a weak publishing support system. The existence of the II languages has not supplanted the dominance of English and Afrikaans as languages of science and technology. Indigenous languages are generally marginalised and underdeveloped as compared to these two languages. Consequently, knowledge, its production and reproduction, is mainly negotiated and constructed in the languages and cultures of the culturally European minority (Prah 2006). One of the ways of promoting multiculturalism, saving and empowering endangered languages is for government to promote recognition, education, and publication in those languages (Bahrom 2007).

Even if policies were in existence, the problem of promoting publishing in indigenous languages in South Africa is compounded by a lack of professionals (i.e. writers, editors, proofreaders and publishers) in the indigenous languages. Tertiary educational institutions shy away from offering courses in publishing. The natural home for most aspects of publishing is library and information science schools as is the case with the University of Pretoria in South Africa, Moi University in Kenya and the University of Science and Technology in Zimbabwe, for example. The intellectual community 
is also neglecting research on publishing in indigenous languages, and there is limited academic engagement on issues of empowering the indigenous languages. However, this may not be said about the Centre for Advanced Studies of African Society (CASAS) based in Cape Town, for instance.

Libraries and librarians are reluctant to stock reading materials in indigenous languages. As a result, librarians fail to meet their obligation to bring new knowledge to society's attention and deny the voices of the indigenous people the right to be heard in many public spaces. Librarians may lament a lack of materials in indigenous languages, but what proactive action have they taken to facilitate the generation of such materials?

\section{Librarians and giving indigenous literature a voice}

Publishers and librarians are gatekeepers and mediators of knowledge. Authors may write whatever they want, but the eventual dissemination of their ideas is largely determined by publishers and librarians. By determining what should appear in print, the publishers control access to information and the means of knowledge distribution. The librarians also have control over access to information. They decide what is to be acquired and made accessible to whom and in what format. In this regard publishers and librarians are "arbiters of literary taste and culture" (Altbach 1976:14). Their respective arbitration and gate-keeping functions in South Africa depend on guesswork as market research and user studies are rarely done. As a result their respective decisions to publish a given manuscript, or acquire and make available certain reading materials, tend not be informed by other considerations.

For example, manuscripts that are expected to be unpopular never see the light of the day. Many works written in indigenous languages do not get published partly for this reason. Librarians and libraries have equally failed indigenous languages. Many public libraries do not stock a significant number of books covering indigenous languages, and thus do not serve the interests of their indigenous clientele. Amadi (198I:12) lamented the lack of focus of libraries on their clientele in Africa in the following words:

It is patently sad that American libraries exist to meet the needs of Americans, and British libraries to meet the needs of the British, while African libraries — because they are both American and British — have neither an

African clientele nor services.

A study conducted by Fredericks and Mvunelo (2003:138) partly confirmed this by showing that collections were predominantly in English and Afrikaans and did not seem to "serve the needs and interests of the cross-section of their communities" because the majority of the people they were supposed to serve in some cases spoke indigenous languages. It is very doubtful that libraries and librarians with this type of orientation will effectively contribute to promoting publishing in indigenous languages by supporting publishers through their purchases.

The publishing industry is in a large part dependent on a viable library system. In South Africa, there is limited interaction between the libraries and librarians on the one hand and publishers and writers on the other. Apparently, there is little meaningful dialogue around the role of each sector in the publishing chain. The library system, for instance, may contribute to the development of publishing. As Okwanya (1985:89) puts it: "[t]he scarcity of libraries in Kenya has made it difficult for indigenous publishers to develop". The need for interaction between librarians and publishers is underscored by the survival of the Afrikaans language and culture. The joint campaign by librarians and publishers to promote Afrikaans literature led to its growth and hegemony (Nassimbeni 1991:45).

It is inconceivable how Altbach (1976:10) does not discuss libraries and librarians as an "important aspect in the distribution chain for books" in his essay. However, almost ten years later he conceded that the book distribution network largely depended on a well developed library system. Even the report commissioned by the Department of Arts, Culture, Science and Technology (1998:5) which aimed at deepening the understanding of the size, nature and dynamics of publishing in South Africa did not mention libraries and librarians as part of the "entire" network of individuals and industries related to the publishing industry. Books and other printed materials may not reach the wider audience without the librarian acquiring them and making them accessible. Libraries in general and public libraries in particular are a potential market for publishers and writers. Librarians may also help publishers to identify gaps in the market and in the conduct of basic market research.

\section{The role of publishing in promoting indigenous languages}

Publishing has an important role in promoting and reviving indigenous languages. Many indigenous language activists are of the view that writing and publishing may keep indigenous languages alive in a dynamic and technologically-driven society. According to Bernard (1997: 143):

For those linguists who want to help preserve language diversity, there are, in my view, two best things to do. One is to help native people develop more language-nest programs. The other is to help native people develop publishing houses. 
The publishing of reading materials in general and of books in particular is important because, in the words of Daniel C. Gilman, first president of John Hopkins University (cited in Okai 2000:153):

Without books, history is silent, literature dumb, science crippled and speculation at a standstill. Without books, the development of civilisation would have been impossible. They are engineers of change, windows of the world, and lighthouses erected in the sea of time. They are companions, teachers, magicians, bankers of treasuries of the mind. Books are humanity in print.

By the same token, publishing is "humanity in print". Publishing includes both the print and the electronic media. The print media includes books, newspapers, magazines, pamphlets and posters. On the other hand, electronic media comprises the internet, radio, television, cinema and video. Ninety percent of the print media in South Africa is in English or Afrikaans with English dominating (Prah 2006: 29).

Most of the daily or weekly newspapers in South Africa are either English or Afrikaans. There are some regional newspapers in isiZulu and isiXhosa. There is also a trilingual newspaper known as Tshivhoni/Seipone/Xivoni in tshiVenda, sePedi and xiTsonga respectively (Nodoba 2002). Although the cover price of the newspaper was RI,00 it was initially distributed free, courtesy of PANSALB. The Sunday Times, South Africa's biggest-selling weekend paper, launched a Zulu edition in 2010. There are no newspapers in the Khoe Khoe and San languages There are few posters and pamphlets written in the indigenous languages, particularly in the Khoe Khoe and San languages. Most of the posters are dominated by English and Afrikaans. Even the instructions on bottles of prescription drugs come only in English or Afrikaans (South Africa's languages ... 20 I I). It is important to promote the publication of newspapers, pamphlets and books in the dying indigenous languages if they are to be revitalised and empowered.

For instance, the hegemony of the Afrikaans language in South Africa was mainly achieved through the promotion of publishing of newspapers, poetry books and other works of prose in the language. A number of authors pushed for the elevation of Afrikaans (Prah 2006). Authors such as Helena Lochner, C.J. Langenhoven and J.H.H. De Waal come to mind. Books were also written in Afrikaans to provide Afrikaner children with books to read in their own language. This helped to elevate Afrikaans as a language of literacy and education. Elevating the Afrikaans language to a written status also raised the profile of the Afrikaners. Already in 1908, D. F. Malan said: "Raise the Afrikaans language, let it become the vehicle of our culture, our history, our national ideals, and you will also raise the people who speak it ... (Adam \& Giliomee 1983: 106). State resources were allocated to facilitate the promotion of the language. The present government seems to have failed to allocate adequate state resources in the implementation of its language policy. In the case of Afrikaans, the role of government, writers, book clubs, publishing and advocacy was crucial in the empowerment and revitalisation of the language.

There is a lot to learn from the Afrikaner experience. Funds were provided by both private and public institutions to create and sustain it. The people who spoke the language were elevated. They were able to fully participate in civil society, and their interests were well-represented. Many Afrikaner writers ventured into writing in their mother tongue when most established Afrikaner authors preferred writing in English. There was sustained support from the library system, as libraries purchased most of the Afrikaans titles.

There is also something to learn from what was known as oppositional book publishers (Philip 1991:9; Martin 1994:26) or "alternative" publishing (Martin 1994:26) if we are serious about promoting publishing in endangered indigenous languages. We are reminded of names such as African Bookman (1943), David Philip Publishers (197I), Ravan Press (1972), Skotaville (1982) and Seriti sa Sechaba (c 1985). Most of these created a new avenue for indigenous authors. Although most of them were foreign funded, their important contribution was that they encouraged and developed publishing works in indigenous languages written by the indigenous people. For instance, the African Bookman was determined to publish "literature suitable in language, content and price for African readers" (Philip 1991:10). Perhaps, that is the approach that should be taken in preserving the endangered indigenous languages such as those of the Khoisan.

Although Philip Publishers were not as unambiguous as the African Bookman in their quest to promote publishing in indigenous languages, their motto: "Books that matter for Southern Africa" (Philip 1991:13) is instructive. So is Skotaville Publishers' motto: "Publishing by the people, for the people". Their efforts of promoting indigenous authors were supported by writers such as Govan Mbeki and Zeke Mphahlele. Writers for the alternative press "undermined the intellectual foundations of the apartheid" regime (Martin 1994:27), and social issues affecting South Africa were objectively fostered. University presses and university institutes also played a role in giving indigenous authors a voice.

Publishing children's literature was, however, not widely promoted by the alternative press. Publishing houses and libraries should encourage children to write and publish books in their indigenous languages. For instance, the Zimbabwe Publishing House (ZPH) used to publish a children's magazine called Ants. The feature stories, illustrations and quizzes in the magazine were written and edited by children between the ages of seven and fourteen (Rathgeber 1985:7I). The only shortfall of the project was that it concentrated on the country's main ethnic and linguistic groups. Recently, the Edward 
Ndlovu Memorial Library in a rural district of Gwanda commissioned a project on children's literature in indigenous languages (Ndlovu \& Moyo 20I2). Unlike the ZPH project, primary school teachers were used instead of children. The library also sponsors short story "writing competitions", amongst rural disadvantaged children.

The Government of Zimbabwe once had a viable community publishing programme which came to an end in 2003 due to the political and economic challenges faced by the country (Chakaodza 2003). Community development officers would decide on a topic of a book in consultation with people in the rural areas and invite literate villagers to write short stories or poems expressing their views and experiences about the chosen topic. The selected stories were then edited by community officers in consultation with the authors. The illustrations for the books and stories were drawn from the community. The manuscript would then be sent to the villagers to test the appropriateness of the stories and changes were made if necessary before the book was finally published. The community publishing approach offers many opportunities to involve people at grassroots level in knowledge production and preservation and it could be used in South Africa with a few adjustments to promote publishing in indigenous languages.

According to Motsaathebe (201 I:126), the concept of a community publishing projected was being experimented with in Cape Town and gave the website address of the project as: $h t t p: / / w w w . c o m m i n i t . c o m / e n / n o d e / / 28580 / 36$. However, a search using that address did not yield any positive results as the internet item could not be found. Higgs (200I) also discusses the launch of the project in August $200 \mathrm{I}$ by the Centre for the Book and NB Books in Cape Town. The project is modelled on different lines from the Zimbabwean one as it is envisaged to "offer mentoring of new publishers by established ones. Writers and community publishers will learn about the crucial importance of marketing and distribution of books" (Higgs 200I). Marketing is one of the key aims of the project. The Community Publishing Programme (CPP) has conducted capacity-building workshops for budding writers throughout the country to empower and develop young writers with relevant skills to hone their talents (National Library of South Africa 1989-20I I). Authors are encouraged to write and publish in their home languages. The question that arises in this context is, should it not be mandatory for the authors to write in indigenous languages? This question cannot be answered here as a discussion of the merits of the CPP approach is beyond the scope of this article.

\section{Sensibility of market forces}

Publishing in South Africa is regarded as a risky business with a low return and relies on an uncertain market. It largely depends on the availability of readers who are willing to buy the books and other printed materials such as newspapers. Publishers thus do not want to invest in books that do not have a wider distribution (St. Clair, Busch \& Webb 1999). The argument is that publishing in a minority indigenous language is not sustainable because publishing and language are "symbiotically" connected (Feather 2003:18). The general logic is that when a language is known by a few people there will be a small market for its books, magazines and newspapers. This in turn makes such a languages unattractive to publishers because the market for the books will be too small. This is a logically powerful argument. However, not all publishers in the trade are primarily motivated by profit (Feather 2003:131). Moreover, "...publishing is more than a means of earning a living. It is a commitment to a broader set of values" (Altbach 1996:ix). Some publishers publish to fulfil a perceived social and cultural role. That is also true of the authors (Ngugi wa Thiongo 2012:1):

Writers and artists value prizes and monetary rewards of course. But they hardly write for monetary prizes and if they did, most would starve to death waiting for returns commensurate with the time invested. My own novels take me anywhere between one to five years to write and when published it takes a few more years to build a loyal readership. The best seller that sells in millions is a very rare beast. But like prophets and seers, writers are driven by a force, an irresistible desire to give to the inner impulses, the material form of sound, color and word.

At this juncture one may pause and ask: when we talk of the lack of the reading culture being inimical to publishing, especially in the indigenous languages, what epistemologies are we using to come to such a conclusion? Are we not running the danger of reinforcing the already entrenched stereotypes that Africans do not read? While we concede that reading is the basis of any publishing and writing programme, how may we conclusively make judgements of the reading culture of any society if:

Reading remains a private act, a personal and individual relationship with a book; it is the environment as whole, as long as it is favourable, which encourages the setting up of this relationship (Gault 1982).

Publishing has flourished in some societies irrespective of economic realities and literacy rates (Altbach 1985:2). Different factors have affected the publishing industry in other societies. The suitability of materials may be one of the major reasons for creating an unfavourable reading environment. Again, we may ask: is the reading environment rooted in local realities? Are the books suitable for the readers? Do we know our readers? Or do we paint them all with one brush that sees things in terms of illiteracy and literacy? By means of whose language is literacy provided, and by using what

SA JnI Libs \& Info Sci 2012, 78(I) 
methods? (Sure 2006:20. The answers to these questions are implied in the questions themselves. Maybe the reading culture is not only defined by high literacy rates.

Watching the television has undermined the pursuit of reading in many highly developed societies. Are these societies still literate? When attempting to answer that question, we must remember that literacy is not static but "dynamic, a bundle of culturally relevant skills" (Compaine 1984:330).

Some of the claims about the reading public are unfounded. For instance, publishers in the world do not know their market and the readers. Many publishing houses are out of touch with what people really want to read because publishing is an industry that lacks market research (Altbach 1976: 10; Chakava 1996:35; Kantey 1991:101; Rathgeber 1985:72). Market research is rarely done and many publishing decisions are made by accountants and executives. Some publishing houses depend on "experience and instinct" (Rathgeber 1985:72). The need for making decisions informed by market research and proper statistics is underscored by the Book Development Council of South Africa (1997:35), Breytenbach (1994:23), Chakava (1996:35) and van Rooyen (2005:25). Reading needs of people change over time. Every generation has its own tastes and preferences. Consequently, at a particular point in time people tend to want to read particular books and other reading materials. There is thus a need to take decisions informed by market research all the time.

The general impression is that the market place is small due to the poor reading culture and low purchasing power among indigenous people. The questions that immediately come to mind are: how small is the "small" market place? Has the market been segmented in order to provide products that are fit for purpose? Is there not a syndrome of "we will write and publish the books and they will buy and read them"? Why is the incidence of leisure reading low in South Africa as compared to achievement reading? In other words, how can people buy and read materials that depict strange places and people whose way of living does not bear the slightest resemblance to their own? How can one read for pleasure materials that are alien to the reader's context and thus hard to relate to? Does this not contribute to the so-called low literacy level? Is a person literate only when they can read and express ideas in official languages? Does literacy in that sense not become a vehicle for alienating indigenous people from their own cultures? The questions are themselves the answers, illustrating the fact that the whole question of literacy needs to be redefined and reconfigured in the context of local realities.

Maybe the texts are not tailored to the needs and requirements of users and are not presented in the cultural and language perspectives of the readers. People would buy books if the books appealed to them in some special way. The fact of the matter is that there is a lack of published material in indigenous languages and written by indigenous people. There is also a lack of information on what publications are needed or wanted in what language.

From a geopolitical point of view, the book market in South Africa with a fairly large population of indigenous people may be said to be the largest in east and southern Africa. We concede that advertising and distributing books written in indigenous languages may be a challenge. The turnover from this market is slow and publishers thus tend to shy away from it. Self-publishing may be one of the ways of dealing with the challenge. In Nigeria, for instance, many writers have turned to self-publishing to deal with the apathy of publishing houses towards titles they perceive to be unprofitable. Whatever route is chosen, writers and publishers should attend to satisfying the market needs both in quality and value as a starting point (Okonkwo 2000:56). The internet offers self-training in various publishing skills, thus making selfpublishing a reality (Zell 200I).

The hurdles of promoting a minority language were partially overcome by the Afrikaners in South Africa and the Tonga in Zimbabwe. These success stories give us hope that market forces are not the only factors that may determine the sustenance and empowerment of a language. The story of Afrikaans was already mentioned above. Now let us briefly look at the Tonga people of Zimbabwe. The Tonga language and culture are synonymous with the Zambezi River that borders Zimbabwe and Zambia. Many Tonga people were displaced on both sides of the river when Lake Kariba was constructed in the 1950s. They were neglected by successive governments. Their language and culture were also marginalised in a country where two indigenous languages - Shona and isiNdebele - were regarded as "national" and Tonga children had to be taught in those languages.

As a matter of fact, since the first school was established in the area in 1924, Tonga was never taught in schools until 2005 (Sauti 2012). Now all that has changed, and a renaissance of the language is well afoot. The chief himself and a group of young educated people have worked together to revive and preserve the Tonga language. Silveira House, a publishing enterprise, worked in conjunction with interest groups such as the Basilwizi (People of the Great River) Trust and other organisations to develop a Tonga curriculum and literature (Sauti 2012). Writing Tonga books remains one of the biggest challenges because as Chief Mola pointed out: "The biggest problem is that we do not have enough of our children who have gone to teachers' colleges or other higher learning institutions" (Sauti 2012). The efforts of the local chief and a handful of Tonga teachers are playing a leading role in ensuring that works are written and published in the Tonga language. The Tonga people are as marginalised as the Khoisan in South Africa. They may thus use the Tonga lesson to 
revive and preserve their own endangered languages. Currently the Tonga language is taught in schools in the area from Grade "R" to Seven. The Tonga case shows that what is needed to revive a dying language is a dedicated champion for a language and the support of those who can read and write. Government has been persuaded to support the initiative.

\section{Writers and the erosion of indigenous languages}

South African writers do not enjoy much public esteem and are not given enough incentives that would encourage them to turn writing into a career, and one can say that the environment is generally unsupportive of writers. Few publishers are interested in supporting and developing the talent of new writers. The situation is worse among writers who desire to publish in indigenous languages. The few writers who are writing in indigenous languages are not receiving the nurturing and attention necessary for emerging writers. Many authors who write in indigenous languages do not receive any payment while writing. Without financial assistance and other forms of support, they write on a part-time basis as they have to find work to sustain themselves and their families. The Centre of the Book realized some of these problems and provided a space for interacting and networking, and small grants for budding writers (National Library of South Africa 1989-20 II). Publishing outlets for indigenous languages are nevertheless limited. Moreover, earnings generated from creative work are not exempted from taxation.

The way that literary awards are made does not help matters either. "Literary awards such as the Nobel, Commonwealth Literature, and even the Africa-centric Noma prizes rarely go to writers in African languages that are, after all, spoken by the majority of Africans" (Limb 2000). The M-Net Book Prize offers R50,000 to a winning novel in each of four language categories: English, Afrikaans, Nguni and Sotho. This means that only one novel title can win in the four-language Nguni category, and only one in the three-language Sotho category, while English and Afrikaans are categories in their own right. Tshivenda and Xitsonga categories get a merit prize of RI6 000 each. On the other hand, the Sanlam Literary Award offers R8 000 each for English, Afrikaans, Nguni and Sotho categories (Mpe I999). It is evident that literary awards discriminate against some indigenous languages resulting in some authors not writing in their indigenous languages.

Despite these systemic constraints which are at times beyond the control of the writers, indigenous and black writers have played a pivotal role in the marginalisation of indigenous languages. There is a prejudice against literary production in African languages. Writers are not confident of producing creative work in indigenous languages (Book Development Council of South Africa 1997). They are also under the impression that works written in indigenous language have a limited market. Consequently, many indigenous authors in South Africa prefer to write in English than to write in their first language.

This does not augur well for publishing in indigenous languages because "... for as long African writers continue to write in borrowed tongues (English, French and Germanic languages), African literature would be closed in a dead end" (Vambe 2006:9). Indigenous authors in South Africa should heed the warning that, "human civilisation stands to lose, by letting some languages languish in neglect while societies rush to embrace the economically and technically powerful ones" (Sure 1999:8).

Indigenous authors in South Africa should take a cue from Ngugi wa Thiongo, a Kenyan writer and social critic. He was writing first in his native Kikuyu to ensure that his people were first to read his novels, plays and social commentaries (Rathgeber 1985:66). He wanted to ensure that the rural people about whom he wrote a great deal were not "denied access to modern Kenyan literature because of their lack of literacy in English" (Rathgeber 1985:66). South African indigenous authors should bear in mind that, "[b]y choosing a particular language as a medium, the African-language writer/performer is also choosing an audience" (Selepe 2001:68). We should have more faith in our indigenous languages and indigenous readers. Already in 1947, Benedict Wallet Vilakazi, the first black man in South Africa to receive a doctorate in literature, said the following: "I have an unshaken belief in the possibility of Bantu languages and their literature, provided the Bantu writers themselves can learn to love their languages and use them as vehicles for thought, feeling and will" (Acoustic Strings 2010).

\section{Utilising electronic publishing to promote indigenous languages}

According to Feather (2003:x), "[t] the domain of publishing is being redefined by social, cultural and technological change". The traditional notions of publishing are being called into question by technological innovations (Altbach 1976: 13; Altbach 1992:13). The definition of publishing has been mainly changed by the availability of new media formats, including digital technology (Eisenhart 1994:2). The widespread adoption and use of digital technology has created new publishing opportunities. Content can be delivered in various formats other than the physical book or newspaper for instance. Electronic publishing has vastly reduced the cost of publishing equipment. The publishing industry and writers thus need to take full advantage offered by the emerging technologies. For instance,

SA Jnl Libs \& Info Sci 2012, 78(I) 
Desk-top publishing has revolutionised the book production process. Editing, formatting, provision of diagrams and illustrations and all other facets of the origination process can now be done on the computer with an array of variations available (Ifaturoti 1997).

As we move further and further into the information society there will be more dependency on electronic information than ever before. Electronic media is going to be increasingly complemented by publishing on the internet. The internet offers numerous marketing opportunities. Self-publishing is within the reach of many people because of advances in information and communication technologies. Although access to new technologies may be a challenge to both the writers and society at large, electronic media have the potential to revitalise and empower endangered indigenous languages.

Many indigenous people in the world are now taking advantage of the multimedia capabilities of the internet. They provide language lessons, cultural music, traditional chants and various sound formats (St. Clair, Busch \& Webb 1999). Some people are blogging and using social media sites such as Facebook and Twitter in their indigenous languages. There are Tweets in South African indigenous languages such as Setswana and Tshivenda (Scannell 20II). Moreover, social media connect communities that are spatially dispersed and provide them with an opportunity to use their languages online in a natural way. Social media may play a vital role in preserving the indigenous languages among the youth and other digital users. The youth should be the major target group when revitalizing indigenous languages because they are losing their native languages due to urbanisation and globalisation.

\section{Data and information on book publishing}

The publishing sector in South Africa is characterized by fragmentation and a dire lack of information about its nature and scope (Book Development Council of South Africa 1997). Data for the UNESCO Statistical Yearbook was last submitted in 1995 (UNESCO 1999). The data for the yearbook are collected from reports submitted by member states. "In accordance with the Constitution of the United Nations Educational, Scientific, and Cultural Organization, each member is requested to report periodically on its laws and regulations and statistics relating to its educational, scientific, and cultural life and activities" (UNESCO 1999). One wonders why the government of South Africa is failing to deliver statistics on its educational and cultural activities to UNESCO when the National Library of South Africa (NLSA) compiles annual statistics giving details on the number of titles catalogued (classified by subject and language), and the amount of copies printed per print run (also classified by subject and language). Perhaps this matter should be given more attention because the UNESCO yearbook is one of the reliable sources of data on cultural activities such as publishing in various parts of the world, even though it is not up to date with the latest information.

The other source that one may think of is the South African National Bibliography (SANB) which until recently was compiled annually by NLSA and made available in print and electronic form using information obtained through the legal deposit system. However, the classification according to the Dewey System is not always helpful for publishers (Book Development Council of South Africa 1997:16). Enforcing the Legal Deposit Act is also a challenge which means that even the statistics from NLSA may not be that accurate. The lack of accurate information on book publishing statistics is not unique to South Africa. The Philippines once experienced similar problems in the 1980s (Salanga 1985: I40).

\section{I Conclusion and recommendations}

The problems raised in this article are by no means a comprehensive audit of the problems related to writers and publishers in South Africa desiring to publish literary works in indigenous languages, but serves to highlight the varied nature of the issues that would need to be addressed in an attempt to change the environment. Publishing and writing is not a silver bullet that will keep indigenous languages alive in South Africa. In addition to the strategies we suggest here, environments should be created in indigenous communities where the indigenous language is used exclusively and nested.

Government departments, municipalities, religious organisations and educational institutions should promote publishing in indigenous languages. They should approach publishers and writers in their communities with specific proposals on publishing in indigenous languages. They might thus be able to revitalise and empower those indigenous languages which are on the verge of extinction. Indigenous language activities, strategies and policies that have proved effective should be shared between communities.

In this article we shared with you one of the strategies that may be used to revitalise and empower indigenous languages in South Africa, that is writing and publishing. For the strategy to succeed government, publishers, authors and librarians in South Africa should play their respective roles as partly outlined below. In order to promote publishing in indigenous languages government should implement immediate and long-term solutions. This is not a call for government's undue influence on the publishing industry, but government (i. e. national, provincial and local) should: 
- mobilise funds from the private and public sectors to initiate and support projects on writing and publishing in endangered indigenous languages (e. g. Community Publishing Projects);

- identify priority research issues, supporting and commissioning such research;

- establish an awareness programme for educated decision makers within and outside government on writing and publishing in indigenous languages, particularly those that are threatened with extinction;

- foster ongoing debate within the publishing industry through workshops, newsletters and meetings on issues of interest and concern to writers and publishers;

- monitor statistics of publishing in endangered indigenous languages in South Africa;

- develop a coherent national language plan; and

- formulate guidelines on the proportion of indigenous literature that should be in a public library collection (Fredericks \& Mvunelo 2003:139).

Publishers and writers as major role players central to the knowledge production and reproduction chain should play a pivotal function in promoting and preserving indigenous languages that are marginalised and endangered. Publishers (larger and smaller) should thus:

- desist from the tendency of promoting writing and publishing in the official languages at the expense of other indigenous languages;

- balance the profit motive and their cultural and social responsibility;

- invest the profits made on best-selling titles and educational books to subsidise and experiment with new talent and ideas;

- bring books into the reach of the rural poor;

- cultivate the reading culture themselves so that they reap the rewards of their efforts (Motsaathebe 20 I I:I23);

- find out through market research what people really want to read and then publish as needed;

- communicate the research on the different language varieties in context;

- build capacity of the smaller publishers through training;

- exploit technology and explore new methods of production in order to reduce the cost of books;

- promote the establishment of sales outlets in rural areas;

- utilise libraries and librarians in the distribution and utilisation of books;

- produce low-cost materials while maintaining high standards in editing, printing and binding (i.e. in the case of hard copies);

- exploit new opportunities in indigenous language publishing;

- take a gamble on young and unknown authors;

- make publishing decisions based on market research; and

- improve the infrastructures of publishing.

On the other hand, authors should:

- familiarise themselves with publishing practices and should prepare their manuscripts in consultation with the publishers;

- discuss their plans, obtain the publishers' approval and guidelines in the preparation of their manuscripts to guarantee publication of the final product;

- communicate with librarians at their local public libraries in order to identify gaps in the market;

- submit proposals of manuscripts to the publishers and librarians at their local public libraries in order to gauge interest in their manuscripts;

- write in their indigenous languages and desist from regarding English as a symbol of advancement and prestige;

- write for both educational and leisure reading; and

- be actively involved in advocacy work, symposiums and workshops on language revitalisation.

Librarians are central to knowledge dissemination in all societies. They seem to neglect their role when it comes to promoting reading and accessing literature in endangered indigenous languages. Librarians (e.g. national, public, special and academic) should thus:

- formulate policies regarding the acquisition of reading materials in indigenous languages;

- identify the market for indigenous literature;

- conduct user studies to establish the reading preferences of their readers;

- contribute to the flow of information about their readership and raise awareness of the state of publishing, specifically 
in indigenous languages;

- promote reading and writing in indigenous languages, for example by having an indigenous language week;

- balance their collections by having imported books, materials published in languages of power and materials written in minority indigenous languages in order to provide a basis of sustained literacy;

- establish mobile libraries (automobile, donkey/horse-drawn mobile libraries, etc.) for indigenous communities as libraries are concentrated in urban centres (this has been successfully tried in rural Zimbabwe) (Moyo 20I2); and

- have a readily available and up-to-date directory of publishers including their focus areas and specialisation.

\section{References}

Acoustic Strings. 2010. Dearth of indigenous African languages? [Online]. deonsimphiweskade.blogspot.com/.../death-ofindigenous-african-languages.html (Accessed I 8 January 20I2).

Adam, H. \& Giliomee, H. 1983. The rise and crisis of Afrikaner power. Cape Town: David Philip.

Altbach, P. 1976. Publishing in the intellectual system. In: Altbach, P. \& McVey, S. (eds), Perspectives on publishing. London: D.C. Heath and Company, pp. 3-15.

Altbach, P. 1985. Publishing in the third world: some reflections. In: Altbach, P., Arboleda, A. A. \& Gopinathan, S. (eds), Publishing in the third world: knowledge and development. London: Mansell, pp. I-I0.

Altbach, P. 1992. Publishing in the third world: issues and trends for the $2 \mathrm{I}^{\text {st }}$ century. In: Altbach, P. (ed.), Publishing and development in the third world. London: Hans Zell Publishers, pp. I-27.

Altbach, P. 1996. Preface. In: Chakava, H. Publishing in Africa: one man's perspective. Nairobi: East African Educational Publishers, Ltd, pp. ix-xi.

Amadi, A.O. 198I. African libraries: western tradition and colonial brainwashing. Metuchen, N.J.: Scarecrow Press.

Bahrom, B. 2007. Notes on language endangerment. [Online]. http://birdswords.wordpress.com/2007/04/22/languageendangerment/ (Accessed I 8 January 20I2).

Bernard, H.R. 1997. Language preservation and publishing. In: Hornberger, N. H. (ed.), Indigenous literacies in the Americas: language planning from the bottom up. Berlin: Mouton de Gruyter, pp. I39-I56.

Book Development Council of South Africa. 1997. Research report on book development in South Africa. First draft. Johannesburg: Author.

Breytenbach, K. 199I. Book publishing in multicultural South Africa (2). In: Board of South African Library, Book publishing in South Africa for the 1990s: Proceedings of a symposium held at the South African Library, Cape Town 22-23 November 1990. Cape Town: South African Library, pp. 25-28.

Breytenbach, K. 1994. The Afrikaans market. In: van Rooyen, B. (ed.), How to get published in South Africa: a guide for authors. Halfway House (Johannesburg): Southern Book Publishers, pp. 18-25.

Burger, J. 1990. The Gaia atlas of First Peoples: a future for the indigenous world. Ringwood, Victoria: Penguin Books.

Chakaodza, B. 2003. Wither community publishing. The Zimbabwe Herald, (22 December).

Chakava, H. 1996. Publishing in Africa: one man's perspective. Nairobi: East African Educational Publishers, Ltd.

Compaine, B. 1984. Understanding new media. Cambridge, Mass: Balinger Publishing Company.

Department of Arts, Culture, Science \& Technology. 1996. Towards a national language plan for South Africa. A final report. Pretoria: Government Printers.

Department of Arts, Culture, Science \& Technology. 1998. The South African Publishing Industry Cultural Industries Growth Strategy (CIGS). Final report of the Language Plan Task Group. Pretoria: Government Printers.

Dirar, S. 2000. Marketing indigenous languages: Eritrea's success, lessons learnt during the struggle. Proceedings of the Indaba 2000: Millennium Marketplace Conference held in Harare on 3 I July-I August 2000. Harare: Zimbabwe International Book Fair Trust, pp. 70-76.

Eisenhart, D.M. 1994. Publishing in the information age: a new management framework for the digital age. Westport, CT: Quorum Books.

Feather, J. 2003. Communicating knowledge: publishing in the twenty first-century. K. G. Saur: Mnchen.

Fredericks, G. H. \& Mvunelo, Z. 2003. Publication of books in indigenous South African languages and their availability and use in public libraries. South African Journal of Libraries and Information Science, 69(2): I33-139.

Gault. M. 1982. The future of the book, Part 2: the changing role of reading. Paris: UNESCO.

Higgs, C. 200I. Community Publishing Project launched in South Africa. Bellagio Publishing Network, 28, (November). [Online]. http://bellagiopublishingnetwork.com/newsletter28/higgs.htm (Accessed 2 January 20 I2).

Ifaturoti, D. 1997. The information age and African publishing. Bellagio Publishing Network, 2I, (December). [Online]. http:// bellagiopublishingnetwork.com/newsletter2 I/ifaturoti.htm (Accessed 24 January 20I2).

Kantey, M. 1991. New approaches to marketing and distribution. In: Board of South African Library, Book publishing in South Africa for the 1990s: Proceedings of a symposium held at the South African Library, Cape Town 22-23 November 1990. Cape Town: South African Library, pp. 100-I I 7.

Kraus, M. 1992. The world's languages in crisis. Language, 68:4-10.

Kum'a Ndumbe III, P. 2007. Raising citizen awareness in the learning of African languages: approach and experience of the Africavenir Foundation in Cameroon. In: Alexander, A. \& Busch, B. (eds), Literacy and linguistic diversity in a global perspective: an intercultural exchange with African countries, Strasbourg Cedex: European Centre for Modern Languages, Council of Europe Publishing, pp. 39-48.

Limb, P. C. 2000. The writer, the publisher, and their languages. Review of Altbach, P. G. \& Teferra, D. (eds), Publishing in African languages: challenges and prospects. H-AfrLitCine, H-Net Reviews. [Online]. http://www.h-net.org/reviews/ showrev.php?id=4359 (Accessed 6 January 2012). 
Martin, R. 1994. "Alternative” publishing. In: van Rooyen, B. (ed.), How to get published in South Africa: a guide for authors. Halfway House (Johannesburg): Southern Book Publishers, pp. 26-3I.

McLaughlin, E.S. 2008. Language, democracy, and governance in South Africa. Webb, V. \& du Plessis, T. (eds), The politics of language. Arcadia, Pretoria: Van Schaik Publishers, pp. II8-137.

Mdletshe, C. 2012. Litigation on languages. The Times (February 29). Saxonwold, Johannesburg: Avusa Ltd.

Moseley, C. (ed.). 2010. Atlas of the world's languages in danger. 3rd edn. Paris: UNESCO Publishing. [Online]. http:// www.unesco.org/culture/en/endangeredlanguages/atlas (Accessed I 9 January 20I2).

Motsaathebe, G. 20II. Book publishing in indigenous languages in South Africa: challenges and opportunities. INDILINGA: African Journal of Indigenous Knowledge Systems, I (I):II5-I 27.

Moyo, O.T. 2012. "Donkey drawn mobile libraries project" and partnership with Karibu Tanzania Association. A paper presented at the Zimbabwe Library Association/ - The International Association of School Librarianship (IASL) Africa subSahara regional School Library Seminar on Libraries in the $21^{\text {st }}$ Century: Learning from each other, held in Bulawayo, Zimbabwe, 8-9 February 2012.

Mpe, P. 1999. Language policy and African language publishing in South Africa. Bellagio Publishing Network Newsletter 25 (July). [Online]. http://www.bellagiopublishingnetwork.com/newsletter25/mpe.htm (Accessed 2I February 20I2).

Mutloatse, M. 1992. Indigenous publishing in South Africa: the case off Skotaville Publishers. In: Altbach, P. (ed.), Publishing and development in the third world. London: Hans Zell Publishers, pp. 21 I-222.

Nassimbeni, M. 1991. Libraries and publishers. In: Board of South African Library, Book publishing in South Africa for the 1990s: Proceedings of a symposium held at the South African Library, Cape Town 22-23 November 1990. Cape Town: South African Library, pp. 40-59.

National Library of South Africa. 1989-20II. Centre for the Book: Community Publishing Programme. [Online]. http:// www.nlsa.ac.za/index.php?option =com_content\&view=article\&id=90\&ltemid = I4I (Accessed I February 20I2).

Ndlovu, J. and Moyo, V. T. 2012. School libraries for reading skills. A paper presented at the Zimbabwe Library Association/ The International Association of School Librarianship (IASL) Africa sub-Sahara regional School Library Seminar on Libraries in the $21^{\text {st }}$ Century: Learning from each other, held in Bulawayo, Zimbabwe, 8-9 February 2012.

Ngugi wa Thiong'o. 1986. Decolonising the mind. London: James Currey.

Ngugi wa Thiong'o. 2012. Speaking my language. Sunday Times: Review, June 24.

Nodoba, G. 2002. Many languages, different cultures: effects of linguicism in a changing society. In: Duncan, N., Gqola, P. D. Hofmeyr, M., Malunga, F \& Mashinge, M. (eds), Discourses on difference, discourses on oppression. Cape Town: The Centre for Advanced Studies of African Society (CASAS). CASAS Book Series No, 24, pp. 335-35I.

Okai, A. 2000. Writers and the media: manufacturing a million readers for the millennium market or the reincarnation of the sculpted image and the giftee's vision. Proceedings of the Indaba 2000: Millennium Marketplace Conference held in Harare on 31 July-I August 2000. Harare: Zimbabwe International Book Fair Trust, pp. I49-I53.

Okonkwo, L.U. 2000. Marketing African books: the Nigerian experience. Proceedings of the Indaba 2000: Millennium Marketplace Conference held in Harare on 3I July-I August 2000. Harare: Zimbabwe International Book Fair Trust, pp. 5 I-64.

Okwanya, F.O. 1985. Publishing in Kenya. In: Altbach, P., Arboleda, A. A. \& Gopinathan, S. (eds), Publishing in the third world: knowledge and development. London: Mansell, pp. 87-95.

Ouane, A. and Glanz, C. 20I I: Executive summary. Optimising learning, education and publishing in Africa: the language factor. A review and analysis of theory and practice in mother-tongue and bilingual education in sub-Saharan Africa. Hamburg: UNESCO Institute for Lifelong Learning (UIL) and Tunis Belvédère: Association for the Development of Education in Africa (ADEA) / African Development Bank, pp. 23-46. [Online]. http://unesdoc.unesco.org/images/002 I/002 I 26/2 I 2602e.pdf (Accessed 3I January 20I2).

Pan South African Language Board. n. d. [Online]. http://www. Pan South African Language Board - SouthAfrica_info.mht (Accessed II January 2012).

Philip, D. I99I. Book publishing under and after apartheid. In: Board of South African Library, Book publishing in South Africa for the 1990s: Proceedings of a symposium held at the South African Library, Cape Town 22-23 November 1990. Cape Town: South African Library, pp. 9-2I.

Prah, K.K. 2003. Silenced voices: studies on minority languages of Southern Africa. Cape Town: The Centre for Advanced Studies of African Society (CASAS). CASAS Book Series No, 34.

Prah, K.K. 2006. Challenges to the promotion of indigenous languages in South Africa. [Online]. http://www.casas.co.za/ FileAssets/NewsCast/misc/file/204_CV_Challenges\%20to\%20the\%20Promotion\%20of\%20Indidegous\%20Languages\%20in\% 20Sou.pdf (Accessed 17 January $201 \overline{2})$.

Rathgeber, E.M. 1985. The book industry in Africa, 1973-1983: a decade of development. In: Altbach, P., Arboleda, A. A. \& Gopinathan, S. (eds), Publishing in the third world: knowledge and development. London: Mansell, pp. 57-75.

Reiner, P. 20I I. Promise and pitfalls - a commercial view of publishing in African languages. In: Ouane, A. \& Glanz, C (eds). Optimising learning, education and publishing in Africa: the language factor a review and analysis of theory and practice in mothertongue and bilingual education in sub-Saharan Africa. Hamburg: UNESCO Institute for Lifelong Learning (UIL) and the Association for the Development of Education in Africa (ADEA): Tunis Belvédère, pp. 3II-380. [Online]. unesdoc.unesco.org/images/002 I/002 I 26/2 I 2602e.pdf (Accessed 28 January 20 I 2).

Reyhner, J. 1999. Some basics of indigenous language revitalization. In: Reyhner, J., Cantoni, G., St. Clair, R. N. \& Parsons Yazzie, E. P. (eds), Revitalizing indigenous languages. Flagstaff, AZ: Northern Arizona University, pp. v-xx.

Salanga, A.N. 1985. Publishing in the Philippines. In: Altbach, P., Arboleda, A. A. \& Gopinathan, S. (eds), Publishing in the third world: knowledge and development. London: Mansell, pp. I38-I5I.

Sauti, L. 2012. Keeping Tonga language alive. A post on Progressive African Library and Information Activists - Zimbabwe. [Online] http://www.facebook.com/lazarussauti\#!/groups//46536472054345/permalink/3/2560458785278/ (Accessed 28 February 2012).

SA Jnl Libs \& Info Sci 2012, 78(I) 
Scannell, K. 20I I. Indigenous Tweets.com. [Online] http://borel.slu.ed/ (Accessed 28 February 20I2).

Selepe, T. J. 200I. "Looting killed" the audience: African-language writing, performance, publishing and the audience. Literator, 22(3):59-74.

Shannon, C.E. \& Weaver, W. 1949. The mathematical theory of communication. Urbana, IL: University of Illinois Press.

Sithole, J. 200I. African indigenous languages endangered. [Online]. http://www.afrol.com/Categories/Culture/ cul0 14 languages_die.htm (Accessed 18 January 20I2).

Sommer, G. 1992. $\bar{A}$ survey on language dearth in Africa. In: Brenzinger, M. (ed.), Language death: factual and theoretical explorations with special reference to East Africa. Berlin: Mouton de Gruyter, pp. 303-314.

South Africa. 1996. The Constitution of the Republic of South Africa, 1996. Act No. 108 of 1996. Pretoria: Republic of South Africa Government Gazette, Volume 378, No. 17677.

South Africa's languages: tongues under threat. 20II. The Economist (20 January). [Online]. http://www.economist.com/ (Accessed 17 February 2012).

Spio-Garbrar, E. 2000. Welcome. Proceedings of the Indaba 2000: Millennium Marketplace Conference held in Harare on 31 July-I August 2000. Harare: Zimbabwe International Book Fair Trust, pp. I I- 12.

St. Clair, R. N., Busch, J. \& Webb, B. J. 1999. Self-publishing indigenous language materials. In: Reyhner, J., Cantoni, G., St. Clair, R. N. \& Parsons Yazzie, E. P. (eds), Revitalizing indigenous languages. Flagstaff, AZ: Northern Arizona University, pp. I29-I37.

Sure, K. 1999. Bilingual education on uneven playfield: the Kenyan case. Journal of Third World Studies, I6(I): I-I0.

Sure, K. 2006. English language teaching and identity crisis in Africa: illustrations from Kenya. In: Mutasa, D.A. (ed.) African languages in the $21^{\text {st }}$ Century: the challenges. Brooklyn Square, RSA: Simba Guru Publishers, pp. $13-45$.

Thondhlana, J. 2002, Using indigenous languages for teaching and learning in Zimbabwe. In: Burnaby, B \& Reyhner, J. (eds), Indigenous languages across the community. Flagstaff, AZ: Northern Arizona University, pp. 31-39. [Online]. http:// jan.ucc.nau.edu/ jar/ILAC/ (Accessed I I January 20I2).

Vambe, M.T. 2006. African languages in the $21^{\text {st }}$ century - language identity and power. In: Mutasa, D.A. (ed.), African languages in the $21^{\text {st }}$ Century: the challenges. Brooklyn Square, RSA: Simba Guru Publishers, pp. 9- 12.

Van Rooyen, B. 2005. Get your book published in 39 (relatively) easy steps: a hands-on guide for South African authors. Johannesburg: Penguin Books.

Webb, V. 2002. Language in South Africa: the role of language in national transformation, reconstruction and development. Philadelphia: John Benjamins.

UNESCO. 1999. Book production UDC classes. [Online]. http://stats.uis.unesco.org/unesco/TableViewer/ tableView.aspx?Reportld=202 (Accessed 31 January 2012).

Zell, H. 200I. The Internet, e-commerce and Africa's book professions. Bellagio Publishing Network, 28, (November). [Online]. http://bellagiopublishingnetwork.com/newsletter28/zell.htm (Accessed 24 January 20I2). 